\title{
JOHN HUNTER: PIONEER OF FREEZE-FRACTURE
}

by

\section{STOLINSKI*}

IT IS generally appreciated that the name of John Hunter (1728-1793) is linked with early important researches on thermal regulation in living organisms. This work is well documented in his treatise on Of the heat, etc. of animals and vegetables, published in $1779 . .^{1}$ It would, however, not have been apparent until recently, that in the same publication a procedure known today as freeze-fracture was also foreshadowed. This technique, which has been developed only within the last decade or so, ${ }^{2,3}$ is now recognized among biologists as of particular promise and importance.,5

The freeze-fracture technique utilizes a particular property of frozen tissues, which on fracture, reveal their solid internal components in a three-dimensional recognizable form. Cell and organelle membranes, in particular, are well represented by large areas, on which a variety of structures can be discerned with good detail, in a face-on configuration (Figure 1). The technique permits the observer to view fully hydrated tissues in their frozen and dormant form, which is very close to the living state and without recourse to the usual chemical treatments. On the whole, this new technique provides a fresh approach to many problems of ultrastructural morphology. Basically, the method relies on rapid freezing of glycerol-impregnated tissues placed in a metal holder, their subsequent fracturing, and observation of replicas of the revealed fracture faces in an electron microscope.

It is worth noticing that almost two hundred years ago a method devised by John Hunter ${ }^{6}$ shows very close parallels to the present-day freeze fracture technique. No doubt contemporary interests and writings related to the subject of freezing had some influence on his line of experimentation. The effect of cold on various organisms as well as biologically important fluids must have puzzled men with enquiring minds for many centuries. Francis Bacon (1561-1626) is said to have died as a direct result of an interest in this matter. In the winter of 1626 whilst driving near Highgate, he desired to discover whether cold could be used to preserve flesh from putrefaction. He stopped his carriage, purchased a hen, had it killed, and with his own hands assisted in stuffing it with snow. He was seized with a sudden chill and cold which brought on bronchitis, as a result of which he died within a few days. ${ }^{7}$ Other famous names can also be associated with similar studies as well as with observations on the effects of low temperatures on survival of living organisms. In 1665, Boyle published his extensive observations which concerned the survival of aquatic animals after

*C. Stolinski, M.Phil., Department of Biophysics, St. Mary's Hospital Medical School, University of London, London, W2 1PG. 


\section{Short Articles}

they have been completely surrounded by ice. ${ }^{8}$ Conradt in Poland in the year 1677 published an account of experiments where changes in density of blood, urine and other biologically important fluids associated with freezing were described. ${ }^{9}$ It is of interest to note that Conradt was acquainted with the researches of Robert Boyle in England, and corresponded with him. Early in the eighteenth century, in France, Réaumur ${ }^{10}$ found that caterpillars of one species survived freezing much better than those of others. This led him to a more detailed examination of caterpillar blood and he observed substantial differences in freezing points of blood of two species. Similarly in 1776 Spallanzani ${ }^{11}$ in Italy froze various insect eggs and noted their survival after subjecting them to low temperatures. Both Réaumur and Spallanzani noticed also in their experimental objects the effect known today as super-cooling, which they regarded as a prerequisite for survival. These types of observations have been confirmed recently by the discovery that certain frost-hardy insects contain in their blood up to 20 per cent free glycerol, ${ }^{12}$ which acts as a very efficient antifreeze and which is extensively used today as a cryoprotectant in the preparation of tissues prior to freezing in the freeze-fracture technique.

Most notable among early workers, however, was John Hunter who also turned his interest towards the subject of freezing. ${ }^{13}$ During the very severe winter of 1777 , he decided to perform experiments in order to find out how much truth there was in the current popular belief that animals could survive complete freezing. He was able to produce temperatures in the vicinity of $0^{\circ} \mathrm{F}$ (approximately $-16^{\circ} \mathrm{C}$ ) by mixing ice and sea salt, and using this mixture he found that the blood would freeze, at a temperature of $25^{\circ} \mathrm{F}$ (approximately $-4^{\circ} \mathrm{C}$ ). From this result Hunter proposed that animal tissues should also freeze near the same temperature. The apparatus he devised to demonstrate it bears such a close resemblance in principle to that used in modern freeze-fracture technique, that a quotation is justified:

In January 1777 , I mixed salt and ice till the cold was about $0\left[0^{\circ} \mathrm{F}\right.$, approx. $-16^{\circ} \mathrm{C}$. $]$, on the side of the vessel was a hole, through which $I$ introduced the ear of a rabbit. To carry off the heat as fast as possible, it was held between two flat pieces of iron that went farther into the mixture. That part of the ear projecting into the vessel became stiff, and when cut did not bleed; and the part cut off by a pair of scissars flew from between the blades like a hard chip. ${ }^{14}$

Further on he stated, "I froze the tail of a tench (as high as the anus) which became as hard as a board". ${ }^{15}$

Hunter used very successfully the technology available to him in order to construct apparatus, which was then employed to its full capabilities. The similarities between his method and the one used today are very striking. The use of the two flat iron bars, between which the tissue was placed, illustrates very well an original attempt towards rapid freezing. In current freeze-fracture technique rapid and efficient freezing of live tissue placed in a metal holder is routinely performed in order to minimize injury to it. Hunter's recognition that the frozen tissue is "as hard as a board", ${ }^{16}$ forms the basis of the present-day technique. His attempt to fracture that solid tissue with a pair of scissors evidently in order to test further its properties, underlines the importance of the experiment. In modern apparatus flying "hard chips", ${ }^{17}$ of tissue are produced in a very similar way to the one described so vividly 


\section{Short Articles}

by Hunter. Finally, Hunter's observation of the freshly exposed blood vessels which after fracturing "did not bleed", 18 but evidently presented a solid appearance, identifies him as the first individual to freeze-fracture and investigate living tissue in this fashion. He experimented on many other small animals and parts of live creatures and examined them in the apparatus described. Freshly dissected muscles of lambs, combs and wattels of young cocks, tails of gold fish, various eggs, tree saplings and seeds, were subjected to freezing. Out of this extensive collection of objects, the rabbit ear (Figure 2), which Hunter himself froze and fractured almost two hundred years ago, survives to our times. Today it can be seen together with the non-frozen control ear in an excellent state of preservation at the Hunterian Museum of the Royal College of Surgeons.

Hunter's pursuit in the field of cryobiology led him also to consider the possibility of reviving whole live creatures which had been frozen. However, after their gradual thawing, they did not revive, and were pronounced dead. Hunter's disappointment may be felt from his conclusions:

... Till this time I had imagined that it might be possible to prolong life to any period by freezing a person in the frigid zone, as I thought all action and waste would cease until the body was thawed. I thought that if a man would give up the last ten years of his life to this kind of alternate oblivion and action, it might be prolonged to a thousand years; and by getting himself thawed every hundred years, he might learn what had happened during his frozen condition. Like other schemers, I thought I should make my fortune by it; but this experiment undeceived me. ${ }^{19}$

According to one of Hunter's biographers, this was for some time his favourite inquiry and ".... . Whilst his friends Lynn and Benjamin West, therefore, were warming themselves with a bout of skating on the Serpentine, Hunter staid at home freezing his fingers in pursuit of his philosopher's stone."20

\section{ACKNOWLEDGEMENTS}

To Professor A. S. Breathnach of Anatomy Department I am indebted for valuable comments and for permission to reproduce the micrograph, and to Miss Elizabeth Allen, Curator of the Hunterian Museum, for helpful suggestions.

\section{REFERENCES}

1. J. Hunter, 'Of the heat, etc. of animals and vegetables', Phil. Trans. R. Soc. Lond., 1779, 68: 7-49.

2. R. L. Steere, 'Electron microscopy of structural detail in frozen biological specimens', J. Biophys, Biochem. Cytol., 1957, 3: 45-60.

3. H. Moor, R. Mühlethaler, H. Waldner, and A. Frey-Wyssling, 'A new freezing ultramicrotome', ibid., 1961, 10: 1-13.

4. H. E. Huxley and A. Klug, 'A discussion on the new developments in electron microscopy with special emphasis on their application in biology', Phil. Trans. R. Soc. Lond., 1971, B 261 : 119-142.

5. E. M. Benedetti and P. Favard (eds), Freeze-etching, techniques and applications, Paris, Société Francaise de Microscopie Électronique, 1973.

6. Hunter, op. cit., note 1 above. 


\section{Short Articles}

7. C. Drinker-Bowen, Francis Bacon. The temper of a man, London, Hamish Hamilton, 1963.

8. R. Boyle, New experiments and observations touching cold, London, Printed for J. Crook, 1665.

9. I. Conradt, Dissertatio medico-physica de frigoris natura et effectibus, Gdańsk, Typis et sumptibus Monastarii Olivienis, 1667.

10. R. A. F. de Réaumur, Mémoires pour servir a l'histoire des insectes, Tome II, Paris, Imprimerie Royale, 1736, pp. 141-147.

11. L. Spallanzani, Opuscoli di fisica animale e vegetabile, Modena, Presso la societa tipografica, 1776, pp. 64-75.

12. R. W. Salt, 'Role of glycerol in producing abnormally low super-cooling and freezing points in an insect, Braco cephi (Gahan)', Nature, Lond., 1958, 181 : 1281.

13. Hunter, op. cit. note 1 above.

14. Ibid., p. 34.

15. Ibid., p. 37.

16. Ibid., p. 37.

17. Ibid., p. 34.

18. Ibid., p. 34.

19. J. F. Palmer (ed.), The works of John Hunter F.R.S. with notes, London, Longman, 1835, vol. 1, p. 284.

20. Drewry Ottley, 'The life of John Hunter', ibid., vol. 1, p. 57, 

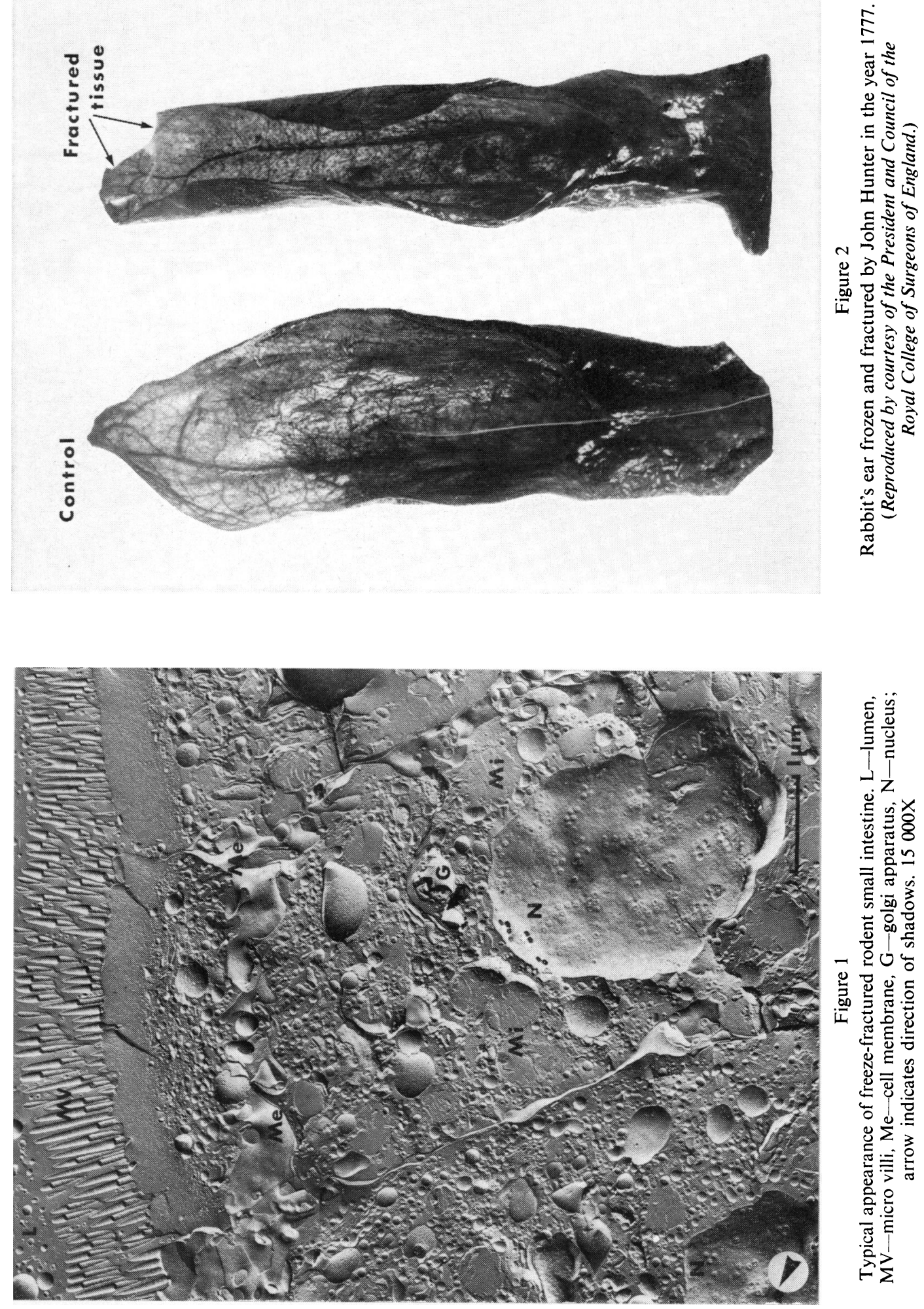